\title{
DENGAN SI APIK, INSYA ALLAH LAPORAN KEUANGAN JADI LEBIH APIK (STUDI PADA UMKM MIKA HIJAB)
}

\author{
${ }^{1 *}$ Ali Tafriji Biswan, ${ }^{2}$ Abdul Aziz, ${ }^{3}$ Nastiti Wirastuti, ${ }^{4}$ Yoga Arif Wicaksono \\ Akuntansi, Politeknik Keuangan Negara STAN, Tangerang Selatan, Indonesia \\ Email : ${ }^{*}$ altafz2009@gmail.com
}

Manuskrip: Desember -2021; Ditinjau: Desember -2021; Diterima: Januari -2022; Online: Januari-2022; Diterbitkan: Januari-2022

\begin{abstract}
ABSTRAK
Cukup besarnya peran bisnis kerakyatan Usaha Mikro, Kecil, dan Menengah (UMKM) bagi perekonomian bangsa tidak diragukan lagi. UMKM sudah menopang sektor riil demikian baik, ikut menyangga pembangunan dan mendorong roda ekonomi. Meski demikian, gerak langkah UMKM untuk maju tidak terlepas dari kendala atau permasalahan. Salah satu kendalanya adalah akses dan penggunaan alat bantu pembukuan yang belum sepenuhnya diketahui. Dengan demikian, harapan pembukuan dan pelaporan keuangan yang lebih sesuai dengan standar akuntansi belum sepenuhnya terwujud. Hal ini bisa berpengaruh pada kurang memadainya evaluasi kinerja bisnis UMKM dan kurangnya peluang mendapatkan alternatif pendanaan agar bisnis berkembang lebih maju lagi (mengingat salah satu syarat mengajukan pendanaan adalah ketersediaan laporan keuangan yang baik). Program pengabdian UMKM ini memberikan alternatif UMKM membukukan transaksinya dengan mudah dan efisien menggunakan aplikasi Si Apik rancangan Bank Indonesia dan Ikatan Akuntan Indonesia. Program ini mendampingi "UMKM contoh" melalui upaya identifikasi dan analisis transaksi, pencatatan dan input data transaksi ke aplikasi hingga pelaporan keuangan. Hasil program ditanggapi positif pihak UMKM karena pendampingan pembukuan berbasis aplikasi memberikan alternatif solusi yang dapat diterapkan sewaktu-waktu, murah, dan efisien. Apalagi di era digital, penggunaan aplikasi akuntansi sangat relevan untuk pengembangan bisnis UMKM.
\end{abstract}

\section{Kata Kunci: UMKM, Akuntansi, Laporan Keuangan, Si Apik}

\section{PENDAHULUAN}

\section{Gambaran Umum UMKM dan Kontribusinya}

Hampir sebagian besar kondisi bisnis pada Usaha Mikro, Kecil, dan Menengah (UMKM) cukup baik sebelum Covid-19. Namun, saat terjadi Covid-19 keadaan berbalik, yakni 56,8\% UMKM berada dalam kondisi buruk, hanya 14,1\% UMKM yang masih berada kondisi baik (katadata.co.id/umkm, 2020). Hal ini diperkuat oleh studi Amri (2020) bahwa omzet pelaku UMKM dan koperasi mengalami penurunan sangat signifikan akibat Covid-19 sejak kemunculannya pada akhir 2019. Penurunan performa bisnis ditunjang juga dengan kurangnya 
aspek pemodalan. Jika dikaitkan dengan pengembangan usaha, survei Pricewaterhouse Coopers (PwC) 2019 menyebutkan bahwa 74\% UMKM ternyata belum mendapat akses pembiayaan.

Disadari bahwa jumlah UMKM di negeri ini cukup signifikan. Menurut Badan Pusat Statistik (BPS), jumlah pelaku bisnis UMKM mencapai 64 juta. Angka ini mencapai lebih dari $90 \%$ keseluruhan usaha yang beroperasi di Indonesia (keuangan.kontan.co.id, 01/02/2021). Dengan jumlah yang cukup signifikan itu dapat dipahami jika ada sementara pendapat bahwa UMKM dinilai lebih tangguh menghadapi krisis ekonomi silam. Salah satu buktinya melalui penyerapan tenaga kerja (Hafni dan Rozali, 2015).

Mengingat jumlah UMKM cukup signifikan dan kerentanan kemunduran bisnis, penting bagi pihak terkait dan regulator mengantisipasi kemunduran usaha ini dan mengusulkan solusinya. Pemerintah menggagas bantuan usaha UMKM melalui skema Pemulihan Ekonomi Nasional (PEN), seperti relaksasi Kredit Usaha Rakyat (KUR), subsidi bunga, modal kerja, serta Bantuan Presiden (Banpres) Produktif untuk usaha mikro dalam bentuk hibah. Hal ini tidak dapat dilepaskan dari target indeks inklusi keuangan Indonesia menjadi di atas 90\% dalam waktu 3 tahun ke depan sesuai dengan Instruksi Presiden. Survei terakhir 2019, indeks inklusi mencapai 76,2\% (wartaekonomi.com, 15/10/2020). Pemberdayaan UMKM akan meningkatkan keberlangsungan bisnis UMKM yang secara otomatis meningkatkan inklusi keuangan.

Umumnya pelaku UMKM memiliki keterampilan spesifik, produksi, dan area pemasaran yang masih terbatas. Aset dan nilai penjualannya pun memiliki batasan khusus sebagaimana ditunjukkan pada Tabel 1.

Tabel 1. Batasan Aset Bersih dan Penjualan UMKM (UU No. 20 Tahun 2008 tentang Usaha Mikro, Kecil, dan Menengah

\begin{tabular}{|l|c|c|c|}
\hline No & Kategori & $\begin{array}{c}\text { Aset Bersih } \\
\text { (maksimal) }\end{array}$ & $\begin{array}{c}\text { Penjualan } \\
\text { (maksimal) }\end{array}$ \\
\hline 1 & Mikro & Rp50 juta & Rp300 juta \\
\hline 2 & Kecil & Rp50 juta & Rp500 juta \\
\hline 2 & Menengah & Rp300 juta & Rp2 milyar \\
\hline
\end{tabular}

Secara regulasi, pemerintah menaruh perhatian pada UMKM, misalnya melalui PP No. 7 Tahun 2021. PP ini mengatur kembali penyesuaian modal usaha atau hasil penjualan tahunan.

Jika ditilik dari karakter keterampilan menjalankan usaha, UMKM menjalankan bisnis sudah spesialis. Menjadi pertanyaan berikutnya adalah bagaimana mengembangkan usaha agar terus bertumbuh.

Berdasarkan survei Pricewaterhouse Coopers (PwC) 2019 di atas, akses pembiayaan dapat memberi peluang UMKM untuk mengembangkan bisnis. Ternyata peluang itu masih minim. Salah satu penyebab minimnya akses pembiayaan adalah kurangnya pemahaman terkait inklusi keuangan (https:/www.pwc.com, 28/06/2019). Salah satu wujud nyata kurangnya pemahaman inklusi keuangan adalah pembukuan. Dikutip dari suara.com 05/07/2919, Perusahaan Umum Jaminan Kredit Indonesia (Perum Jamkrindo) mengungkap alasan UMKM sulit mendapat pinjaman dari 
perbankan adalah minimnya laporan keuangan yang disusun dengan baik oleh UMKM. Padahal laporan keuangan UMKM dibutuhkan oleh bank untuk mengetahui kemampuan UMKM mengembalikan pinjaman. Berdasarkan laporan keuangan dari masa ke masa (komparatif) yang disajikan UMKM, bank atau lembaga keuangan lainnya juga dapat mengukur kemampuan UMKM jika UMKM meminta pinjaman lebih besar lagi.

Studi Febriyanto, Soegiono, dan Kristanto (2019) terhadap 65 UMKM di Kabupaten Demak menyimpulkan bahwa UMKM yang melakukan pencatatan keuangan dan memanfaatkan informasi keuangan cenderung memperoleh akses pembiayaan. Informasi laporan keuangan UMKM dapat membuka akses pendanaan bagi pengembangan bisnisnya. Hal ini karena UMKM mendapatkan tambahan dana sebagai penambah modal usaha, misalnya diwujudkan untuk membeli alat-alat yang lebih efisien.

Kesadaran UMKM menyusun laporan keuangan yang baik juga dapat meningkatkan disiplin pengelolaan keuangan, misalnya tidak mencampuradukkan pembukuan keuangan usaha dengan keuangan pribadi. Hal ini tidak terjadi pada entitas selevel Perusahaan Perseroan (PT) karena umumnya PT telah menerapkan praktik pembukuan lebih baik sehingga laporan keuangan juga terstandar.

Sudah jamak diketahui bahwa penyusunan laporan keuangan perlu diakomodasi melalui pengaturan standar akuntansi. Meskipun tidak sekomprehensif PT, Standar Akuntansi Keuangan Entitas Mikro, Kecil, dan Menengah (SAK EMKM) akhirnya dapat diterbitkan Ikatan Akuntan Indonesia dan sudah berlaku efektif sejak 2018 (iaiglobal.or.id). Hingga kini SAK EMKM masih hangat diperbincangkan pada UMKM. Sebagaimana pernyataan Perum Jamkrindo sebelumnya, banyak UMKM yang belum memahami cara menyusun laporan keuangan, padahal laporan keuangan merupakan instrumen penting melaporkan transaksi keuangan aktivitas bisnis UMKM. Oleh karenanya UMKM harus mempelajari akuntansi sederhana penyusunan laporan keuangan. Menariknya, akuntansi sudah dianggap sebagai bahasa bisnis (Islam dan Syarif, 2017). Layanan pembukuan UMKM berbasis aplikasi pun bermuculan.

Secara sederhana laporan keuangan mengakomodasi transaksi keuangan yang dicatat menggunakan asumsi akrual yakni pendapatan dan biaya diakui pada saat timbulnya hak dan kewajiban, tidak harus pada saat diterima kas atau dibayarkan kas.

\section{Profil dan Rumusan Permasalahan}

Dewasa ini, sektor usaha UMKM sedang marak-maraknya berkembang di masyarakat, mulai dari makanan, minuman, furniture, kerajinan, fashion, dan lainlain. Saat pandemi, masyarakat menjalankan usaha secara online.

UMKM merupakan usaha ekonomi produktif yang berdiri sendiri dan dimiliki oleh perorangan. UMKM memiliki peranan dalam pembangunan, penciptaan lapangan pekerjaan, pemerataan pendapatan, pertumbuhan ekonomi, dan yang tidak kalah penting adalah pengentasan kemiskinan.

Banyaknya peran dan manfaat UMKM kepada negara, tidak menjadikannya lepas dari kendala dan masalah. Salah satunya adalah kendala dalam proses akuntansi, 
seperti proses mencatat, mengolah, dan menyajikan transaksi-transaksi menjadi laporan keuangan. Hal tersebut bisa berakibat pada sulitnya dalam pengembangan UMKM karena masalah pendanaan. Setiap UMKM pasti ingin usahanya berkembang menjadi lebih besar dan oleh karena itu, diperlukan adanya hubungan dengan pihak bank atau lembaga keuangan. Pihak bank atau lembaga keuangan biasanya menyaratkan laporan keuangan yang bisa dijadikan dasar dalam pemberian kredit, maka dari itu, ketidakmampuan dalam penyusunan laporan keuangan menjadikan terhambatnya UMKM dalam mengembangkan usahanya apabila memerlukan pinjaman pihak lain.

Program pengabdian masyarakat ini mengambil topik edukasi penyusunan laporan keuangan UMKM sesuai standar akuntansi. Program mencakup pendampingan pembukuan, pembuatan video tutorial pembukuan, dan edukasi melalui sesi Zoom.

Program pengabdian mengambil UMKM contoh yakni Mika Hijab. Profil singkat mitra Mika Hijab adalah UMKM bergerak di bidang fashion busana dan asesoris muslimah, berkedudukan di Sragen Jateng. Meski di era pandemi, usaha masih bertahan dan meningkat seiring dengan inovasi dan kreasi produk yang sesuai kekinian

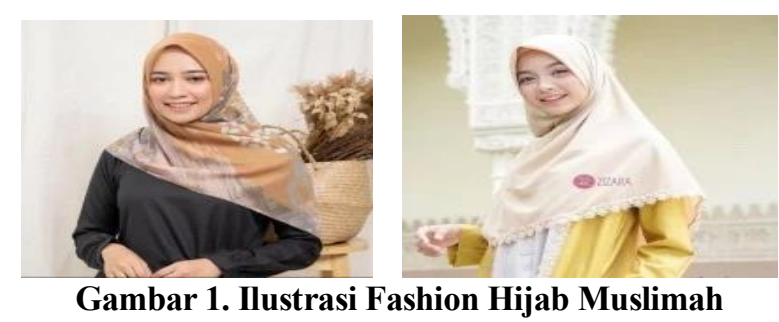

Berdasarkan penggalian data dan informasi selama pendampingan, permasalahan yang dihadapi sebagai berikut:

1. masih terbatasnya akses informasi bagi UMKM terkait teknik pembukuan kegiatan operasional UMKM,

2. masih terbatasnya pihak yang memberi edukasi menyasar langsung pada kebutuhan UMKM dalam pembukuan dan penyusunan laporan keuangan,

3. perlunya kemudahan dalam praktik pembukuan dan pembuatan laporan keuangan

\section{HASIL DAN PEMBAHASAN}

Berangkat dari permasalahan (1) keterbatasan akses informasi informasi bagi UMKM terkait praktik pembukuan kegiatan operasional UMKM, (2) keterbatasan pihak yang memberi edukasi menyasar langsung pada kebutuhan UMKM dalam pembukuan dan penyusunan laporan keuangan, dan (3) perlunya kemudahan dalam praktik pembukuan dan pembuatan laporan keuangan, program pengabdian masyarakat berupa pendampingan dan edukasi ini dilakukan.

Diskusi tim menghasilkan ide baik yakni pemanfaatan aplikasi pembukuan yang memudahkan praktik akuntansi UMKM. Aplikasi ini haruslah gratis, mudah diakses, dan mudah dipahami. Tim juga mewajibkan diri membuat tutorial simulasi 
transaksi untuk kemudahan menggunakan aplikasi. Tim juga harus memberi penjelasan ketika UMKM mengalami kesulitan penggunaannya. Pilihannya jatuh pada aplikasi Si Apik, dapat diunduh di Play Store.

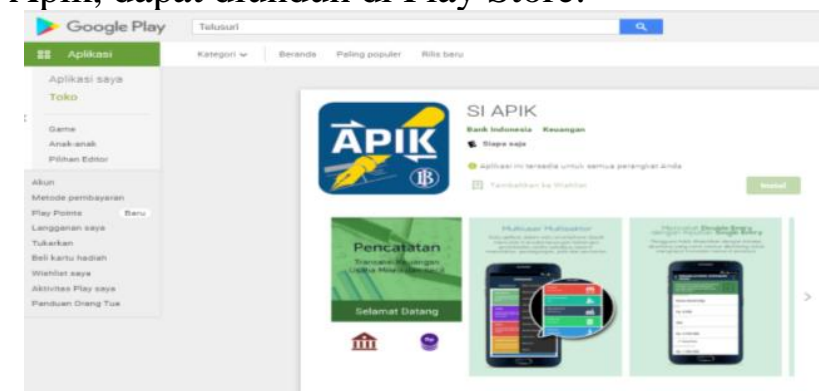

Gambar 2. Aplikasi Si Apik

Si Apik adalah aplikasi akuntansi yang dapat mencatat jenis transaksi sederhana bagi UMKM. Standar pencatatan mengacu pada standar yang disusun oleh Bank Indonesia bersama Ikatan Akuntansi Indonesia.

Aplikasi Pencatatan Informasi Keuangan (Si Apik) merupakan aplikasi akuntansi yang dikembangkan Bank Indonesia yang dapat digunakan untuk mencatat transaksi keuangan secara mobile menggunakan perangkat smartphone berbasis Android dan iOS. Aplikasi ini dikembangkan dengan mengacu kepada Pedoman Pencatatan Transaksi Keuangan yang disusun oleh Bank Indonesia bersama Ikatan Akuntansi Indonesia serta Standar Akuntansi Keuangan Entitas Mikro, Kecil, dan Menengah (SAK EMKM).

Dengan menggunakan media Si Apik tersebut, pendampingan pembukuan UMKM Mika Hijab dapat dilakukan. Berikut ini tanggapan atas permasalahan yang dihadapi di lapangan.

Tabel 2. Solusi Permasalahan

\begin{tabular}{|l|l|l|}
\hline No & Permasalahan & Jawaban/Solusi Pengmas \\
\hline a. & $\begin{array}{l}\text { Masih terbatasnya akses informasi } \\
\text { bagi UMKM terkait teknik praktik } \\
\text { pembukuan kegiatan operasional } \\
\text { UMKM }\end{array}$ & $\begin{array}{l}\text { Tim mencarikan teknik praktik pembukuan } \\
\text { UMKM yang mudah didapat yakni aplikasi Si } \\
\text { Apik yang bisa diakses free, sumbangsih dari Bank } \\
\text { Indonesia dan IAI untuk UMKM negeri }\end{array}$ \\
\hline b. & $\begin{array}{l}\text { Masih terbatasnya pihak yang } \\
\text { memberi edukasi menyasar langsung } \\
\text { pada kebutuhan UMKM dalam } \\
\text { pembukuan dan penyusunan laporan } \\
\text { keuangan }\end{array}$ & $\begin{array}{l}\text { Tim melakukan pendampingan melalui pendataan } \\
\text { dan simulasi praktik pencatatan dan pelaporan } \\
\text { keuangan sehingga dapat diikuti prosesnya }\end{array}$ \\
\hline $\begin{array}{l}\text { Perlunya kemudahan dalam praktik } \\
\text { pembukuan dan dan pembuatan } \\
\text { laporan keuangan }\end{array}$ & $\begin{array}{l}\text { - Tim melakukan pendampingan dan komunikasi } \\
\text { terkait praktik pembukuan } \\
\text { mendokumentasikan keluaran dalam } \\
\text { Tim } \\
\text { bentuk video ringkas sehingga bisa dipelajari } \\
\text { ulang } \\
\text { Tim membuka ruang diskusi terkait pencatatan } \\
\text { dan pelaporan jika mitra pengmas mengalami } \\
\text { kesulitan-kesulitan } \\
\text { Tim juga siaga jika sewak-waktu ditanya } \\
\text { keberlanjutan pendampingan }\end{array}$ \\
\hline
\end{tabular}


Solusi yang ditawarkan juga selaras dengan kompetensi pelaksana program pendampingan UMKM ini yakni terdiri atas tenaga pengajar D3 Akuntansi dan mahasiswa D3 Akuntansi yang telah menempuh mata kuliah Pengantar Akuntansi dan Akuntansi Keuangan Menengah.

Untuk menghasilkan intisari program didukung kerja Abdul Aziz, Nastiti Wirastuti, dan Yoga Arif Wicaksono. Pengumpulan data dan pendadaran objek dibantu Cicilia Eka Yunita, menyamakan persepsi dan mengumpulkan bahan awal berikut medianya. Pembuatan keluaran digagas oleh Familia Paradisa, yang dalam pelaksanaannya dibantu Ilham Indra Wijayanto, Nanda Chaechilia Fadhillah, Roni Adi Santoso, memantapkan rencana program dan ruang lingkup. Lalu review oleh Salma Ndaru Kelana, yang dalam pelaksanaannya dibantu Shinta Bertha Rahmaningrum, menyusun laporan kegiatan sesuai hasil diskusi. Rincian kegiatan ditunjukkan sebagai berikut.

Tabel 3. Ringkasan Kegiatan

\begin{tabular}{|c|c|}
\hline Tahapan & Kegiatan \\
\hline Penyamaan persepsi & Membahas topik, keluaran, dan referensi \\
\hline $\begin{array}{l}\text { Pematangan rencana } \\
\text { program }\end{array}$ & $\begin{array}{l}\text { Membuat rencana program mengacu pada pembahasan topik dan } \\
\text { keluaran }\end{array}$ \\
\hline Pelaksanaan & $\begin{array}{l}\text { - Mengunduh aplikasi Si Apik di Play Store untuk dipelajari } \\
\text { - Mendampingi dan berkomunikasi dengan mitra terkait praktik } \\
\text { pembukuan dan membuat simulasi transaksi } \\
\text { - Membuat dan merevisi video simulasi penggunaan aplikasi Si } \\
\text { Apik untuk pembukuan transaksi mitra } \\
\text { - Memberikan video simulasi untuk dipelajari mitra Mika Hijab } \\
\text { - Diskusi melalui zoom meeting }\end{array}$ \\
\hline Finalisasi dan evaluasi & $\begin{array}{l}\text { Komunikasi akhir, finalisasi, dan evaluasi kegiatan (membandingkan } \\
\text { antara target kegiatan dengan realisasi) }\end{array}$ \\
\hline
\end{tabular}

Dalam program ini tim mencatat umpan balik dari mitra. Mika Hijab menyambut baik pendampingan dan pemaparan tim terkait aplikasi. Mika Hijab berpendapat pembukuan melalui aplikasi Si Apik mudah diterapkan. Mika Hijab dapat menggunakan aplikasi Si Apik ini sebagai alternatif pencatatan keuangan apabila sistem keuangan yang dimiliki sedang mengalami masalah atau dapat digunakan untuk cabang lain yang belum menggunakan sistem keuangan. Karena Si Apik merupakan wawasan baru bagi mitra, tim tidak memaksakan mitra menggunakannya. Tim harus tetap "andap asor" bahwa Si Apik ditawarkan sebagai opsi media pembukuan.

Setelah melakukan pencermatan penggunaan aplikasi Si Apik, mitra dapat membandingkannya dengan sistem keuangan yang saat ini dipakai. Satu hal yang mendapat penekanan tim adalah sistem apapun itu bisa berguna sepanjang sesuai kebutuhan dan selaras dengan standar akuntansi. Pembandingan itu butuh waktu. Maka, program pendampingan dapat dilanjutkan ke depan jika diperlukan, baik oleh tim rintisan yang sama atau tim lain kader berikutnya.

Review tim atas aplikasi SI Apik ini bahwa aplikasi dirancang Bank Indonesia berkolaborasi dengan Ikatan Akuntan Indonesia sehingga mumpuni. Si Apik turut menyumbang niat pemerintah mengembangkan pembukuan UMKM. Si 
Apik juga mudah diakses, murah, dan cukup akurat. Insya Allah laporan keuangan yang dihasilkan pun akan lebih apik. Sewaktu-waktu mitra dapat memanfaatkan laporan keuangan yang apik itu sebagai syarat untuk mendapatkan suntikan pendanaan dari pemerintah, bank, atau lembaga keuangan lainnya.

Hendaknya laporan keuangan merepresentasikan realiti bisnis. Laporan keuangan UMKM yang dapat dibuat ditunjukkan pada Tabel 4.

Tabel 4. Laporan Keuangan UMKM

\begin{tabular}{|l|l|l|}
\hline No. & Jenis Laporan Keuangan & Isi Laporan Keuangan \\
\hline 1 & Laporan Posisi Keuangan (Neraca) & $\begin{array}{l}\text { Aset, utang (termasuk utang bank), dan ekuitas } \\
\text { (modal) }\end{array}$ \\
\hline 2 & Laporan Laba Rugi & $\begin{array}{l}\text { Pendapatan, beban, dan laba/rugi pada periode } \\
\text { berjalan }\end{array}$ \\
\hline 3 & Catatan Atas Laporan Keuangan & Melengkapi informasi laporan keuangan \\
\hline
\end{tabular}

Sumber: Diolah dari Gambaran Umum SAK EMKM iaiglobal.or.id

Bagi pihak pengguna laporan, Laporan Posisi Keuangan (Neraca) dapat digunakan untuk menilai kekayaan mitra, utang, dan modal. Bank atau lembaga keuangan dapat menganalisis Laporan Posisi Keuangan (Neraca) mitra dalam hal kemampuan membayar utang, misalnya Rasio Lancar melalui rumus (Aset Lancar)/(Utang Lancar). Untuk UMKM, rasio ini penting karena meyakinkan peminjam bahwa pinjamannya terkembalikan. Laporan Laba Rugi mengikhtisarkan jumlah pendapatan dikurangi jumlah beban (laba jika pendapatan lebih besar, dan rugi jika beban usaha lebih besar). Laporan Laba Rugi mitra mengukur kinerja bisnis sehingga dianggap lebih menarik dibandingkan Laporan Posisi Keuangan. Diharapkan laba bersih mitra terus meningkat sehingga bisnis bertumbuh.

Dalam era pandemi yang bercirikan pembatasan interaksi sosial, aplikasi juga menawarkan efisiensi sejalan perkembangan teknologi. Hal ini sejalan dengan studi Arianto (2020) bahwa pengembangan UMKM digital telah menjadi alternatif penyelamatan sekaligus pengembangan kewirausahaan digital di Indonesia pada masa pandemi Covid-19. Aplikasi juga mendukung kepraktisan dan fleksibilitas penggunaannya (Putranto, 2020).

\section{KESIMPULAN}

Berdasarkan data dan pembahasan, disimpulkan bahwa pembukuan memiliki arti penting bagi keberadaan usaha. Laporan keuangan yang disusun secara konsisten sesuai ketentuan akan memberikan manfaat bagi UMKM yakni apakah usaha sudah berkembang atau belum. Jika usaha mulai berkembang, UMKM terus bertumbuh hingga bisnis memberi manfaat tidak hanya bagi pelaku usaha tetapi juga memperbaiki taraf hidup masyarakat dan menyumbang pertumbuhan ekonomi nasional. Jika usaha belum berkembang, mungkin diperlukan tambahan pembiayaan ke bank atau lembaga keuangan lainnya agar dapat menutupi kekurangan dan meningkatkan potensi usaha. Yang patut diingat, bank dan lembaga keuangan juga akan melihat laporan keuangan UMKM agar mendapatkan keyakinan dalam mengucurkan dana pinjaman atau utang. Mengingat keberpihakan pemerintah kepada UMKM melalui program inklusi keuangan dan bantuan 
keuangan cukup nyata, UMKM harus menunjukkan niat baik menjalankan bisnis. Bisnis yang baik itu juga dicerminkan pada pembukuan yang baik sehingga menghasilkan laporan keuangan yang berkualitas.

Berdasarkan hasil kegiatan pengabdian kepada masyarakat, disimpulkan juga bahwa mitra Mika Hijab menyambut baik pemaparan penggunaan aplikasi Si Apik. Hal ini bisa menjadi alternatif pembukuan keuangan apabila sistem keuangan yang dimiliki sedang mengalami masalah atau dapat digunakan untuk cabang lain yang belum menggunakan sistem keuangan.

Tim juga memberikan gagasan bahwa setelah dicermati penggunaan aplikasi Si Apik, mita Mika Hijab atau UMKM lainnya hendaknya membandingkan sistem keuangan (akuntansi) eksisting dengan aplikasi baru. Tentu sistem itu berguna sepanjang sesuai kebutuhan dan selaras dengan standar akuntansi. Gagasan ini dapat diwujudkan dan dikembangkan pada program pendampingan UMKM masa mendatang.

\section{DAFTAR PUSTAKA}

Amri, Andi, 2020, Dampak Covid-19 Terhadap UMKM di Indonesia, Jurnal Brand, Vol. 2 No. 1 (2020).

Arianto, Bambang, 2020, Pengembangan UMKM Digital di Masa Pandemi Covid19, ATRABIS: Jurnal Administrasi, Vol. 6 No. 2 (2020): Vol 6 No 2 (2020).

Febriyanto, Dwi Panggah, Like Soegiono, dan Ari Budi Kristanto, Pemanfaatan Informasi Keuangan dan Akses Pembiayaan Bagi Usaha Mikro Kecil dan Menengah, Jurnal Ilmiah Akuntansi dan Humanika, Vol. 9, No. 2 (2019).

Hafni, Roswita dan Ahmad Rozali, 2015, Analisis Usaha Mikro, Kecil, dan Menengah Terhadap Penyerapan Tenaga Kerja di Indonesia, Ekonomikawan: Jurnal Ilmu Ekonomi dan Studi Pembangunan, Vol. 15, No. 2 (2015).

Haryadi, R. N., Rojali, A., \& Fauzan, M. (2021). Sosialisasi Penggunaan Online Shop berbasis Website di UMKM Cimanggis. Jurnal Pengabdian Masyarakat Madani (JPMM), 1(1), 10-16.

Islam, Md. Rafiul dan Md. Amir Sharif, 2017, Accounting as a Language of Business: A study for conceptual understanding, IJRM: International Journal of Scientific Research and Management, Vol. 5 No. 11 (2017).

Katadata.co.id/umkm, 2020.

Keuangan.kontan.co.id, 01/02/2021.

Lutfi, A. M., et al. (2021). Pengaruh Capital Adequacy Ratio Dan Bopo Ratio Terhadap Return On Asset Pada PT. Bank Muamalat Indonesia, Tbk Periode 2010-2019. Jurnal Ekonomi Efektif, 3(3), 420-428.

Peraturan Pemerintah No. 7 Tahun 2021 tentang Kemudahan, Pelindungan, dan Pemberdayaan Koperasi dan Usaha Mikro, Kecil, dan Menengah.

Putranto, Rizky Bayu, 2020, Implementasi Mobile Application Akuntansi UKM pada UMKM Sektor Industri Coklat Olahan, Prosiding Simposium Nasional Keuangan Negara hal. 273-292. 